\title{
Immature Cell Count
}

National Cancer Institute

\section{Source}

National Cancer Institute. Immature Cell Count. NCI Thesaurus. Code C96672.

The determination of the amount of immature cells present in a sample. 